\title{
Korea's 1997 Financial Crisis: Causes, Consequences and Prospects
}

\section{Hyun-Hoon Lee}

$\mathrm{F}$ or over three decades before the financial crisis in 1997, Korea had experienced very high growth rates. Prior to 1996, Korea enjoyed an annual growth rate of its real GDP of over eight per cent for over thirty years. Accordingly, its GDP soared from US\$2.1 billion in 1961 to US $\$ 484.4$ billion in 1996 and its per capita income rose from US\$82 to US\$10,543 over the same period. In 1996 Korea had the world's eleventh largest GDP. In December 1996 Korea joined the Organisation for Economic Cooperation and Development (OECD) as the twenty-ninth member country. Less than a year after its admission to the OECD, however, Korea experienced a severe financial crisis. This article provides an overview of the underlying and direct causes of the financial crisis, and then reviews the IMF's immediate stabilisation policy and the structural reform efforts made by the Korean government (see also Smith, 1999). Finally there is a brief discussion of the prospects for the Korean economy.

\section{Causes of the Financial Crisis}

\section{Fundamental weaknesses}

The Korean crisis had its roots in fundamental economic weaknesses that had accumulated in the process of government led rapid growth. These weaknesses of the economy were exposed from the late 1980s onwards. The government's economic policy that was considered to have led the nation to its remarkable economic performance in the 1960s, 1970 s and $1980 \mathrm{~s}$, was no longer suited in the 1990 s as the Korean economy became larger and more complex and as global competition intensified. Instead, excess government involvement in the economy caused inefficiency, over-capacity and imbalances in many sectors.

The political sector had its ties with some businesses, intervening in the process of extending loans to huge family-controlled conglomerates or chaebols and in deciding major state-funded projects for political kickbacks in return. Accordingly, capital, production and exports were heavily skewed towards chaebols, with myriad cross-guarantees on borrowing and limited transparency and accountability. And a 'too big to fail' mentality of chaebols resulted in their

Hyun-Hoon Lee is Associate Professor in the Division of Economics and International Trade at Kangwon National University, Korea, and currently Visiting Fellow in the Department of Economics at The University of Melbourne. 
excessive risk-taking, over-investment and insufficient attention to credit and exchange rate risks. Over-indebtedness, over-capacity and poor earning power among chaebols were a natural outcome. By the end of 1997, the top 30 chaebols had debt-equity ratio of 519 per cent, a sharp contrast with 154 per cent in the United States and 193 per cent in Japan.

In addition, the excessive government control of the banking system made banking institutions rely more on government intervention than on profit-first business. This, in turn, resulted in misguided extensions of bank loans to nonviable or insolvent borrowers. Thus, the active government involvement in the market resulted not only in corruption, but also in moral hazard and inefficiency in the general economic sector, and a weakening of the competitiveness of enterprises and banks. In aggregate, these practices left Korea vulnerable to shocks in an increasingly globalising financial market.

On the other hand, since the advent of democratisation in 1987 and the subsequent liberalisation of trade unions, nominal wages had increased 15 per cent per annum until 1996, exceeding productivity growth of 11 per cent. However, tight labour market conditions and strong trade union power ensured there was no labour market reform. The labour market was full of rigidities. An excessive degree of job protection prevented lay-offs and encouraged overmanning, inflexible working hours and few limits on strike action (Fitch ICBA, 1999).

More critical than the rapid rise in the wage rate and labour market rigidities was that the Korean education system no longer provided the economy with the labour force it needed. As the Korean economy moved toward the level of developed countries, its products became more sophisticated and its production processes became more complex and more deeply integrated into the world economy. Thus, with rapid growth, Korea was in urgent need of a creative and highly skilled labour force - entrepreneurs, workers, bankers and the like. However, the Korean education system had not kept pace with economic development and still retained its repetitive memory-oriented methods that had proved successful in earlier periods.

\section{Unfriendly environment}

Since the late 1980s Korean companies had faced intense competition from foreign companies in both domestic and international markets. Competition came mainly from the rapid opening of Korea's domestic market and the rapid catch-up growth of the newly industrialising countries of Asia. In 1989, Korea announced that it would no longer restrict trade for the sake of its balance of payments (as covered in GATT Article XVIIIB) and it would follow Article XI, further increasing its pace of import liberalisation. With the conclusion of the Uruguay Round and the setting up of the World Trade Organisation (WTO), Korea faced a more rapid opening of its domestic market. Furthermore, former 
President Kim Young-Sam who came to power in 1993 proclaimed that Korea would join the OECD during his term of office. OECD access accelerated opening of the Korean domestic market. As a result, by 1996 the number of import restrictions and the average tariff rates for manufacturing goods were comparable with those of most industrial countries.

Financial markets underwent an even faster opening. During the early 1990s, nearly all restrictions on the inflow and outflow of mobile capital were removed. However, the opening and liberalisation happened with little attention to new kinds of regulation likely to be required when only a thin base of financial skills exists. The liberalised financial systems enabled inexperienced private domestic banks and firms to take out large, dollar-denominated loans from foreign lenders. As a result, the economy became exposed and vulnerable to the instabilities of the international financial markets.

Since the early 1980s China has strongly pursued a so-called 'reform and open-door policy'. This new policy was very successful, and between 1980 and 1996 China's real GDP grew by more than 10 per cent per annum. The rise of China, however, meant new intense competition for Korean firms. China's manufactured exports grew by more than 20 per cent per annum in US dollar terms between 1990 and 1996, and Chinese firms competed directly with Korean firms in textiles, apparel, and electronics. In addition, the rapid catch-up growth of Southeast Asian countries, such as Indonesia, Malaysia, Thailand and the Philippines also led to harsher competition for Korea.

Obviously this new competition put intense pressure on Korea's international competitiveness and hence its exports. Accordingly, to maintain wage rates higher than the newly-industrialising countries, Korea had to change its industrial structure to become more high-tech-oriented. In fact, following the textbook example of Japan, Korea invested a huge amount of capital into the socalled 'strategic industries' such as electronics, automobiles, biochemicals, etc. As a consequence, however, Korean companies found themselves competing directly against Japanese companies in some important industries. Thus, Korea faced a very difficult economic predicament. It had to compete against China and other newly industrialising countries on the one hand, and against Japan on the other. In short, Korea was situated like 'a nut in a nutcracker', as stated first in the Booz Allen \& Hamilton report on the Korean economy, published just before the financial crisis.

Korea faced even more pressure when in January 1994, China devalued the yuan by 50 per cent, and as the Japanese yen progressively depreciated against the US dollar (from $¥ / \$ 85$ in June 1995 to $¥ / \$ 127$ in April 1997). Semiconductor prices also collapsed by as much as 80 per cent in 1996 delivering a severe terms-of-trade shock, for this industry accounted for 20 per cent of Korea's total exports by value. 


\section{Policy mistakes}

Before the crisis, there were increasing signs of the weakening of economic fundamentals and warning symptoms of impending crisis. For instance, export growth relative to import growth, measured in US dollars, began to slow in the mid-1990s. Specifically, exports in US dollar terms increased by just 12.8 per cent per annum between 1990 and 1996, while imports increased by 14.1 per cent per annum during the same period. Accordingly, the current account, which had been in surplus since the mid-1980s, recorded deficits annually since 1990, except for a small surplus in 1993. Most markedly the current account deficit widened sharply to US\$23 billion in 1996 from US\$8.5 billion in 1995 . The ratio of the current account deficit to GDP rose to 4.7 per cent in 1996 from 1.7 per cent in 1995. From 1990 to 1996, the cumulative current account deficit amounted to US $\$ 48.7$ billion, and the current account deficit was financed mainly by inflow of foreign capital. This, in turn, caused a sharp increase in foreign debts. The net external debts increased from US\$3.0 billion in 1989 to US $\$ 52.9$ billion in 1996. The entire external debts increased from US\$29.3 billion in 1989 to US\$157.5 billion in 1996 .

At this point the Korean won should have depreciated to prevent the continuation of current account deficits. Instead, the Korean Government adopted a 'strong won' policy. The strong won policy was maintained with the so-called market average foreign exchange rate system adopted in 1990. The exchange rate was allowed to move within a narrow daily fluctuation band.

Why did the Korean Government insist on a strong won policy? First, to achieve the target of one-digit inflation rate per annum, the Korean government insisted on nominal exchange rate stability. That is, inflation control was the over-riding priority of macroeconomic policy and the exchange rate was an 'anchor' for inflation control. Second, the government maintained the position that a strong won would push Korean firms to strive to increase their productivity and hence international competitiveness. Third, the government wanted to keep the exchange rate stable in order to help domestic corporations and financial institutions by lowering the domestic currency costs of servicing foreign debts denominated in the US dollars. Fourth, a political consideration also made the exchange rate policy less flexible. Having realised its long-held strong desire to achieve a US $\$ 10,000$ income per capita in 1995, the then Kim Young-Sam Government did not want it eroded by a depreciation of the domestic currency.

Inappropriate financial market supervision also turned out to be a serious mistake. As noted above, during the early 1990s, the financial market underwent a very rapid liberalisation and deregulation. This allowed domestic financial institutions to have easy access to foreign capital to finance domestic investment. The problem was that financial liberalisation was implemented without adequate process and provision of a safety net. Financial liberalisation 
was carried out mostly on short-term rather than long-term capital inflows. For instance, the net foreign portfolio investment, which was merely US\$0.1 billion in 1990 , increased dramatically to US\$3.1 billion in 1991 , US $\$ 5.8$ billion in 1992, and US\$10.0 billion in 1993. This upward trend continued until 1996. However, the net direct investment continuously revealed negative values, indicating that foreign direct investment in Korea was smaller than Korea's direct investment overseas.

Also, appropriate supervision and prudential regulation did not accompany financial liberalisation. In particular, the secondary financial institutions such as merchant banks, the number of which increased sharply from six in 1993 to thirty by 1996, were not under appropriate supervision. With the belief that the government would not allow financial institutions to fail, Korean banks borrowed unhedged short-term foreign capital at lower rates, denominated in the US dollar, and made long-term loans at higher rates, with the expectation that they could continually renew short-term borrowing. This led to a serious mismatch in maturities between borrowing and lending. Short-term loans accounted for 63 per cent of the total debts on the eve of the financial crisis. With this fragile structure of foreign debt, Korea became highly vulnerable to the instabilities of the international financial markets.

\section{Exogenous shocks: the trigger}

Eventually, exogenous shocks triggered the Korean financial crisis. There were two different shocks in early 1997: one from within Korea, and the other from outside. Along with the downturn of the economic cycle, a series of large corporate bankruptcies began with Hanbo Steel, the fourteenth largest chaebol in Korea, in January 1997. Before Korea turned to the International Monetary Fund (IMF) for assistance in November, seven of the top thirty chaebols (including the eighth largest, Kia Motors), faced insolvency. This resulted in a surge of non-performing loans held by the commercial banks. At the end of September 1997 non-performing loans of all financial institutions reached W32 trillion (seven per cent of GDP), about double their level at the end of 1996.

On the other hand the financial crisis in Southeast Asia acted in two ways as another trigger for the Korean crisis. First, a large devaluation of the currencies of the crisis countries impeded Korea's already shredded international competitiveness and contributed to strong downward pressure on the Korean currency. Second, trouble in Southeast Asia acted as a 'wake-up call' for foreign investors to re-evaluate risk and thus discover that Korea was already experiencing difficulties in the financial market with the surge in non-performing loans. When the Hang Seng Index of the Hong Kong stock market recorded a large downturn on 23 October 1997, foreign investors panicked and suddenly started to withdraw their investment and cut back their short-term loans to Korea. The won depreciated by about 20 per cent against the US dollar through 
November 30 and the stock market index fell by about 30 per cent to a ten-year low. (The Korea Stock Price Index (KOSPI), which had reached over 1,100 points in 1994, dropped to 600 points in early 1997.) Usable foreign currency reserves declined sharply as the Bank of Korea financed the repayment of shortterm debt of Korean commercial banks' offshore branches.

A series of policy mistakes was also made in response to the exogenous shocks. First, the Korean Government did not properly and swiftly cope with the corporate insolvency, which had a devastating impact on Korea's financial system. The government repeatedly declared that troubled firms would be dealt with on the basis of the market mechanism. However, amid the critical situation in the first half of 1997, the government aggravated the financial turmoil by taking measures counter to market principles such as the Bankruptcy Prevention Accord and state subsidies for the hopelessly ailing chaebols. In particular, the government's decision to convert Kia Motors, the insolvent eighth largest chaebol, into a public enterprise heightened the confusion and distrust among foreign investors.

The government also made a mistake with the exchange rate policy. When speculative attacks on the won began in October and accelerated in November, the government maintained a narrow daily fluctuation band and inexplicably tried to defend the won, wasting valuable foreign exchange reserves. As a consequence, Korea's available foreign exchange reserves fell far below the outstanding short-term foreign debts. In retrospect, if the band had been widened earlier and the exchange rate had been allowed to float freely, the won would have depreciated gradually and would have helped limit the extent of the crisis.

In fact the government underestimated the early signs and denied the possibility of a financial crisis, repeatedly citing its strong GDP growth rates, high savings rates, budget surplus and moderate inflation. Accordingly, even when warnings of the likelihood of a crisis were circulating among foreign investors, it did not react to the signs properly and decisively to prevent the crisis.

\section{The Immediate IMF Program and Structural Reform}

\section{The immediate IMF program}

Korea turned to the IMF on 21 November 1997, as the rollover ratio of shortterm external borrowings by domestic financial institutions kept decreasing and the country's usable foreign currency reserves plummeted to US\$7.3 billion, from US $\$ 22.3$ billion only a month before. On 3 December 1997 Korea and the IMF signed an agreement for a financial aid package totalling US $\$ 58.3$ billion, subject to a broad range of conditions including macroeconomic stabilisation and structural reform. The IMF committed emergency funds amounting to US\$21 
billion. An additional US $\$ 14$ billion was committed by the World Bank and the Asian Development Bank. As a second line of defence, a further US\$23.3 billion was pledged by the United States, Japan, Australia and other interested countries.

When the IMF program was announced the IMF expected that the large financing package and reform plan would be enough to turn around the market sentiment. Accordingly, upon the announcement of the program, only US\$5.5 billion was disbursed, and no discussions on debt rescheduling with international creditors were attempted.

In line with the IMF Stand-By Arrangement, the Korean Government was required to implement tough measures including tight monetary policy and the immediate closure of insolvent financial institutions. As an emergency measure the government was asked to raise interest rates sharply. This measure was expected to stem the outflow of foreign funds and the rapid depreciation of the exchange rate. The call rate was raised from 12.3 per cent on 1 December 1997 to 20.7 per cent on 3 December and further to 30.1 per cent on 23 December. As a consequence, yields on three-year corporate bonds soared from around 14 per cent before the crisis to above 30 per cent, and yields on 91-day commercial paper rose sharply from $13-14$ per cent to peak at 40.8 per cent on 31 December. Broad money growth (M3) was reduced to 13.9 per cent at the end of December 1997 from 16.3 per cent at the end of November 1997. The IMF also asked Korea to take fiscal contractionary adjustments and generate a surplus in 1998 .

Troubled financial institutions were to be closed or, if they were deemed viable, be restructured and/or recapitalised. Nine insolvent merchant banks, which had been suspended on 2 December, were required to submit a rehabilitation plan within 30 days. Where a plan was not approved the institution's licence was to be revoked. The remaining merchant banks were required to present a program of recapitalisation by 31 December 1997 . They were required to meet at least a four per cent capital adequacy ratio of the Bank for International Settlements (BIS) by 31 March 1998. Other commercial banks were also required to prepare a plan to meet the BIS eight per cent minimum requirement by September 1998 . In addition, virtually all capital account restrictions on foreign investors' access to the bond markets were to be lifted as of 1 January 1998.

However, the rollover ratio of short-term debt declined sharply and usable official reserves were almost depleted in mid-December. For example, the rollover ratio of the seven largest commercial banks fell to 32.2 per cent in December from 58.8 per cent in November and 86.5 per cent in October. After a brief increase to 435 on December 6 from 379 on 3 December, the KOSPI kept sliding to reach 351 on 24 December. As the speed of depreciation accelerated the exchange rate rose from about W/US\$1,150 to almost 
W/US $\$ 2,000$ from the beginning to the end of the month. All of these were in fact much worse than the IMF had predicted. ${ }^{1}$

When Korea faced imminent default by 24 December the IMF, backed by the United States, decided to press the foreign commercial banks to roll over their short-term credits on an enforced basis. The IMF insisted on the comprehensive debt rollover as a condition for further disbursements of the IMF lending package. Initially the banks and the government announced a freeze on debt servicing. On 16 January the banks and the government formally agreed to a complete rollover of all short-term debts falling due in the first quarter of 1998. On 28 January an agreement was reached to convert US $\$ 24$ billion in short-term debt into claims of maturities between one and three years. The new arrangements put a brake on the fall of the won and on the decline in the stock market.

\section{Structural reform}

Because the Korean crisis had its roots in weakened economic fundamentals, attempting to stabilise only the financial market without an emphasis on structural reforms was like treating symptoms without addressing the cause. Upon signing the financial aid package on 3 December 1997, the government agreed with the IMF that it would pursue economic reform in the financial sector, the corporate sector, and labour markets. In addition, the government pursued public sector reform to achieve the efficiencies necessary to keep up with the reform in other sectors.

To facilitate reform of the financial sector, the National Assembly passed several economic laws early in 1998, creating the Financial Supervisory Commission (FSC), the Korea Asset Management Corporation (KAMCO) and Korea Deposit Insurance Corporation (KDIC). Authorities closed or suspended the operation of a number of non-viable financial institutions. As of July 1999, 144 financial institutions have been liquidated, 48 have been merged, and 59 have had their licences suspended. Disposal of non-performing loans and recapitalisation has also been an important part of the financial sector restructuring. As of July 1999, KAMCO and KDIC together financed a total of W64 trillion for the financial sector restructuring. Capital market liberalisation and promotion of FDI have also been an important aspect of the financial sector reform. Various measures have been taken by the government to liberalise the capital market and promote FDI. For instance, since May 1998, the foreign

\footnotetext{
${ }^{1}$ This led Radelet and Sachs (1998), among others, to criticise the IMF for its handling of the Asian crisis. Drawing upon the analogy between financial crisis and human stroke, Lee (1999) evaluates the IMF program in Korea. See also Lane et al. (1999) for a systematic review within the Fund of the IMF policy response to the Asian crisis.
} 
equity ownership ceiling has been completely removed and hostile mergers and acquisitions (M\&A) by foreign investors have been allowed.

The creditor banks led the reform of the corporate sector. The top five chaebols and their creditors agreed on debt reduction and other restructuring measures in early 1998. Specifically, they agreed on (1) adoption of consolidated financial statements; (2) compliance with international standards of accounting; (3) strengthening of voting rights of minority shareholders; (4) compulsory appointment of at least one outsider director; (5) establishment of an external auditors committee; (6) prohibition of cross-subsidiary debt guarantees from April 1998, and (7) resolution of all existing cross-debt guarantees by March 2000.

Another element of corporate restructuring involved business swaps referred to as the 'Big Deal' between the top five chaebols. The objective was to streamline investment and enhance efficiency in such key industries as semiconductors, petrochemicals, aerospace, rolling stock manufacturing, power plant equipment, vessel engines, and oil refining. In December 1998, the top five chaebols reached agreement on many of the deals. In addition, the top five chaebols were required to reduce their debt-to-equity ratios and improve their financial structure by asset sales, recapitalisation, and foreign capital inducement.

Legal proceedings for corporate rehabilitation and bankruptcy filing were simplified in February 1998 to facilitate market exit of non-viable firms, and ensure better representation of creditor banks in the resolution process. In May 1998 creditor banks assessed the viability of 313 client firms showing signs of financial weakness, and listed 55 corporations as non-viable. To facilitate the exit of those non-viable corporations, their banks denied them new credit and bailout. As of July 1999 creditor banks have also carried out workout programs for 76 corporations out of 80 candidates, which were subsidiaries of the sixth through to the 64th chaebols in terms of their size. Recently the subsidiaries of Daewoo group, the third largest chaebol, have been included in corporate workout programs as Daewoo faced financial troubles in July 1999.

Labour market reform efforts have also been made. In February 1998, greater labour market flexibility was instituted with the revision of the Labour Standard Act (LSA), which legalised layoffs for 'managerial reasons'. The revision of the $L S A$ facilitated necessary layoffs in the process of financial and corporate sector reforms.

The Tripartite Commission composed of labour, management, and government was established in January 1998 to deal with industrial relations and a wide range of socio-economic matters. The Tripartite Social Accord was signed in February 1998. The Accord includes matters such as the promotion of freedom of association, management transparency and business restructuring, labour market policy, the extension and reform of the social security system, wage stabilisation and the improvement of labour-management cooperation, and 
the enhancement of labour market flexibility. The Accord is a turning point in the history of Korean labour-business relations and corporate culture. However, the Tripartite Commission has experienced ups and downs because labour representatives have not considered it truly beneficial for workers.

In addition to the new $L S A$, legislation allowing the establishment of manpower dispatching businesses took effect in July 1998. Manpower dispatching businesses provide employment-outsourcing services for 26 occupations. This measure is also expected further to enhance labour market flexibility.

Poor productivity and inefficiency in the public sector have been notorious. State-owned enterprises (SOEs) have been subject to overhaul by means of privatisation or management reform. Twenty public institutions of the 109 SOEs were privatised in 1998. The 89 subsidiaries of the 30 parent SOEs are also subject to privatisation or management reform. Out of 24 non-financial SOEs (parent companies), five SOEs are to be privatised by 1999, six SOEs will be gradually privatised by 2002 , while the remaining SOEs are targeted for managerial reform and consolidation. Downsizing of the government is also an important feature of the public sector reform. The government has pursued streamlining of its organisational structure and plans to reduce its employment by 11 per cent by the end of 2000 . In addition, the quasi-government sector, including public institutions and various associations, has been streamlined.

\section{Consequences and Prospects}

\section{Consequences}

As discussed above, the immediate IMF program required the Korean Government to implement tight monetary and fiscal policy, as an emergency stabilisation measure, and hence market interest rates soared to 30 to 40 per cent. As a consequence the financial difficulties of corporations deepened. In addition, because the IMF program required financial institutions to meet the BIS capital adequacy ratios, they became reluctant to provide corporations with funds for fear of incurring new non-performing loans. Even strong banks came under intense pressure as foreign creditors refused to roll over loans and domestic depositors fled to foreign-owned banks. The merchant banks, in particular, which used to provide corporations with short-term funds, virtually suspended new lendings to corporations and tended to refuse rolling over loans as they fell due. This, in turn, made the situation even worse for the debt-ridden corporations, resulting in a boost of the number of insolvencies to three times the pre-crisis level. The ratio of dishonoured bills rose considerably to 2.1 per cent in December 1997 from 0.5 per cent in November 1997. On the other hand, the contractionary prescriptions led to a large reduction in consumption, resulting in a 29 per cent fall in domestic demand in the first quarter of 1998 . 
During the first quarter of 1998 real gross domestic product (GDP) recorded a negative growth rate $(-3.6$ per cent) for the first time in eighteen years. The depth of the slowdown was worse than initially predicted, and hence major macroeconomic projections were revised sharply and successively downward during the course of the program. Also the government and the IMF agreed to reverse the tightening and adopted an expansionary policy in early 1998, as the full extent of collateral damage to the real sector became apparent. (At their meetings in January 1998 they agreed to allow for an increased fiscal deficit. In February 1998 they also agreed to allow for lower interest rates, and the downward adjustment of the rates was implemented over the following months.) But the policy change came too late to prevent the massive economic contraction. The real GDP growth rate recorded -7.2 per cent, -7.1 per cent and -5.4 per cent in the second, third and fourth quarters, respectively. In 1998, real GDP dropped 5.8 per cent on a year-on-year basis.

Almost 1.66 million jobs were lost in 1998 boosting the unemployment rate from less than three per cent before the crisis to 7.9 per cent in December 1998, despite a sharp decline in participation rates. The yearly unemployment rate for 1998 was 6.8 per cent, also in stark contrast to the 2.6 per cent of 1997 . Per capita income remained at about US\$6,300 in 1998, down sharply from US\$9,511 in 1997 and US\$10,542 in 1996, and fell short of the $\$ 6,745$ recorded in 1991.

Meanwhile the current account, which recorded a deficit every month until October 1997, has been in surplus since November 1997. In 1998, the current account recorded a surplus of US $\$ 40$ billion, the largest in history. However, this was brought about mainly by a decline in imports rather than an increase in exports. Despite the potential for increased profitability from the exchange rate depreciation, exporters were also badly affected because those with confirmed orders were unable to obtain trade credits. In 1998 Korean exports declined 2.8 per cent on a year-on-year basis to US $\$ 132.3$ billion, while imports plunged 35.5 per cent to US\$93.3 billion.

\section{Prospects}

Signs of recovery started to appear early in 1999. Real GDP rose 9.8 per cent on a year-on-year basis in the second quarter of 1999 , following a 4.6 per cent rise in the first quarter. In particular, the manufacturing sector grew 20.1 per cent, and machinery and equipment investment grew 37.2 per cent in the second quarter. The growth rate in real GDP is expected to exceed eight per cent in 1999. The unemployment rate decreased to 6.2 per cent in June 1999. The current account balance reached US $\$ 13.6$ billion by the first half of 1999 , and is expected to reach the annual level of US\$21 billion. Thanks to large current account surpluses, Korea's useable foreign exchange reserves grew to a record level of US $\$ 65.5$ billion as of 30 September 1999. The exchange rate has 
strengthened and interest rates have remained at levels below those in place before the crisis erupted. The Korea Stock Price Index has surpassed the precrisis level, up from the low of 298 points in June 1998.

It seems now that the Korean economy has overcome the worst of the crisis and the possibility of a repetition of 1997's external liquidity crisis has been significantly reduced. But the situation calls for caution as there are many obstacles to full recovery. Korea needs to reduce government involvement in business decision-making processes and to create a legal and institutional framework of the market-driven economy that provides rational incentives for economic behaviour. That is, Korea needs to achieve a full paradigm shift on par with global standards, and this will take a rather long time.

There have been tumultuous and painful effects for most of the Korean people in all segments of society. In particular, the crisis has had significant adverse effects on equitable growth. In general, the crisis hit hardest lowincome households and marginal workers such as women, young workers, the less educated, wage workers, and first-time job seekers. As a consequence, the equity of income distribution has deteriorated (Lee and Lee, 1999). Thus, Korea is in urgent need of a range of initiatives to contain the social costs of the financial crisis. In particular, special efforts to strengthen the social protection systems are necessary as it will not otherwise be able to cope adequately with the social consequences of a long period of high unemployment.

On the other hand, there is a possibility that external shocks may re-emerge as the international environment could worsen at any time. There is a risk that the world economy will plunge into recession in the coming years as the situation in the United States and other high-income countries are expected to be volatile. Despite strong denials from the Chinese Government, it becomes increasingly probable that China might depreciate the yuan in the foreseeable future and thus lead to renewed currency instability in East Asia. And an economic collapse of North Korea, which cannot be ruled out, would place a heavy burden on South Korea. Although a full-scale attack by the North on the South seems a remote possibility, acts of desperation borne out of mass starvation can not be ruled out.

In short, there are many internal and external obstacles to full recovery of the Korean economy. If any of the obstacles are not adequately overcome the crisis could turn out to be an even more enduring pain for the Korean people. On the other hand, if positive preconditions are met and the structural reform is accomplished smoothly the crisis could turn out to be a blessing in disguise that will pave the way for the sustainable and equitable growth in Korea for the twenty first century.

\section{References}

Bank of Korea, Data Base in (http:/www.bok.or.kr/kb/princp-e) 
Booz, Allen and Hamilton (1997), Revitalizing the Korean Economy towards the $21^{\text {st }}$ Century, Mael Economic Newspaper Co., Seoul.

Fitch ICBA (1999), Rating Report: Republic of Korea.

Lane, T., A. Ghosh, J. Hamann, S. Phillips, M. Schulze-Ghattas and T. Tsikata (1999), IMFSupported Programs in Indonesia, Korea and Thailand: A Preliminary Assessment, International Monetary Fund Preliminary Copy. http://www.imf.org/external/pubs/ft/op/op178/index.htm

Lee, H-H. (1999), 'A 'Stroke' Hypothesis of Korea's 1997 Financial Crisis', Department of Economics, University of Melbourne (Research Paper No. 696). http://www.ecom.unimelb.edu.au/ecowww/research/696.pdf

Lee, Y-Y, and H-H. Lee (forthcoming), 'Financial Crisis, Structural Reform and Social Consequences in Korea' in Tran Van Hoa (ed.), Social Impact of the Asian Financial Crisis, Macmillan, London.

Radelet, S. and J. Sachs (1998), 'The East Asian Financial Crisis: Diagnosis, Remedies, Prospects', mimeo. http://www.stern.nyu.edu/' nroubini/asia/AsiaHomepage.html

Smith, H. (1999), 'The Failure of Korea Inc.', Agenda 6(2):153-66.

A more detailed version of this paper was presented at seminars at The University of Melbourne, Monash University, The Australian National University and The University of Wollongong. The author is grateful to the participants at the seminars. Special thanks go to Peter J. Lloyd, Charles Harvie and Michael S. Lee for their comments and suggestions. The author also wishes to thank the referees for their comments and scepticism. The suggestions of the Editor have greatly improved the presentation of this paper. All errors are mine. 